ISSN 1392-3196 / e-ISSN 2335-8947

Zemdirbyste-Agriculture, vol. 105, No. 3 (2018), p. 271-278

DOI 10.13080/z-a.2018.105.035

\title{
Mating type idiomorphs of Pyrenophora teres in Turkey
}

\author{
Arzu ÇELİK OĞUZ ${ }^{1}$, Fatih ÖLMEZ², Aziz KARAKAYA ${ }^{1}$ \\ ${ }^{1}$ Ankara University \\ Dışkapı, Ankara, Turkey \\ E-mail: acelik@agri.ankara.edu.tr \\ ${ }^{2}$ Şırnak University \\ Şırnak, Turkey
}

\begin{abstract}
Pyrenophora teres f. maculata (Ptm) and Pyrenophora teres f. teres (Ptt) causes spot form and net form of net blotch diseases of barley, respectively. Although both forms of $P$. teres are morphologically similar, their symptoms and genetic background differ. In this study, 175 single spore (109 Ptm and $66 \mathrm{Ptt}$ ) isolates obtained from different regions of Turkey were evaluated for their mating type distribution and prevalence. Fungal isolates of both forms were verified using species-specific polymerase chain reaction (PCR) primers. For mating type determination studies, duplex PCR was performed using MAT-specific single nucleotide polymorphism primers. Sixty and 49 of 109 Ptm isolates were found as MAT1-1 and MAT1-2 types, respectively and 43 and 23 of 66 Ptt isolates were found as MAT1-1 and MAT1-2 types, respectively. These results show the possibility of sexual reproduction among the Ptm isolates in Turkey and Ptt population of Central Anatolia, Turkey. However, the overall pattern of Ptt isolates did not support the sexual reproduction hypothesis in Turkey. Sexual reproduction in the life cycle of $P$. teres is important since it could lead to genetic and pathogenic variation. As a result of new sexual combinations more virulent pathotypes of $P$. teres may occur.
\end{abstract}

Key words: barley, Drechslera teres f. maculata, Drechslera teres f. teres.

\section{Introduction}

Pyrenophora teres Drechsler (anamorph: Drechslera teres (Sacc.) Shoem.) causing net blotch has two morphologically similar forms, $P$. teres f. maculata (spot form of net blotch) and P. teres f. teres (net form of net blotch) (Smedegård-Petersen, 1971; Liu et al., 2011). Symptoms of the spot form of net blotch consist of small necrotic spots surrounded by chlorosis (McLean et al., 2009; Liu et al., 2011). Symptoms of the net form of net blotch consist of thin, dark brown, longitudinal streaks on leaves. Later, these streaks merge and create irregular streaks on leaves (Liu et al., 2011). Net blotch of barley plants is an important foliar disease in the world. The pathogens cause significant reductions in yield and quality of barley worldwide (Murray, Brennan, 2010). General losses are between $10-40 \%$ although this percentage is much higher in the fields where susceptible barley cultivars are grown (Mathre, 1982). Resistant cultivars, crop rotation and fungicide application are some ways to manage net blotch (Turkington et al., 2011).

A single mating type (MAT) locus controls two mating types (MAT1-1 and MAT1-2) in heterothallic ascomycetes (Kronstad, Staben, 1997; Debuchy, Turgeon, 2006). These two alleles are called idiomorphs (Rau et al., 2005). For pseudothecia formation two fungal strains with different idiomorphs are necessary (Kronstad, Staben, 1997; Rau et al., 2005; Sommerhalder et al., 2006).
Pyrenophora teres is a self-sterile and heterothallic ascomycete fungus and needs to have two mating types for sexual reproduction (Kronstad, Staben, 1997). Both forms of net blotch produce sexual pseudothecia and asexual conidia. In the sexual cycle of the fungus ascospores are produced in pseudothecia which are over-wintering in infected plant debris. In the asexual cycle, airborne conidia spread and cause multicyclic disease (Liu et al., 2011).

Sexual recombination occurs naturally within the net form and spot form isolates, separately in each form of the fungus. In order for sexual reproduction to occur, which is a major source for primary infections, the two mating types have to be present at statistically equal frequencies (Rau et al., 2005; Bogacki et al., 2010). The two mating types found in unequal frequencies are associated with high probability of asexual reproduction through conidia (Sommerhalder et al., 2006; Bogacki et al., 2010). Hybridization between the spot form and the net form, on the other hand, is either very rare or nonexistent in nature; however, it is possible under laboratory conditions (Campbell et al., 2002).

Sexual reproduction in $P$. teres populations does indeed occur (Rau et al., 2005; Bogacki et al., 2010; Fiscor et al., 2014; Akhavan et al., 2015). However, Lehmensiek et al. (2010) reported that in some $P$. teres populations, 
reproduction was mainly asexual. Knowledge pertaining to multiplication through sexual reproduction in net blotch pathogens is crucial to understanding their evolutionary potential (Sommerhalder et al., 2006). The presence of both mating types and sexual recombination could lead to novel genotypes of the fungus. The novel strains of the fungus may as well be more virulent than the present strains. Both Ptm and Ptt isolates show pathogenic variation and have the potential to overcome resistances. Numerous studies have reported pathogenic variation in both forms of net blotch populations from various parts of the world (Lehmensiek et al., 2010; Boungab et al., 2012; McLean et al., 2014; Akhavan et al., 2016; Çelik Oğuz, Karakaya, 2017).

Barley is the second most important cereal crop produced in Turkey after wheat. It is mostly cultivated in the Central Anatolia followed by the Southeast Anatolia. Southeast Anatolia is one of the major gene centers of barley as a part of Fertile Crescent where cereals were firstly cultivated in the world. Surveys revealed that both forms of $P$. teres are present in Turkey; however, the spot form appears to be more common (Karakaya et al., 2014). In addition, several researchers have reported the pathogenic variation of $P$. teres to be high (Yazic1 et al., 2015; Çelik Oğuz, Karakaya, 2017). Nonetheless, there has been no study to date on the presence and prevalence of mating types of both forms of $P$. teres in Turkey.

In this study, MAT-specific single nucleotide polymorphism (SNP) primers were used to determine the presence and frequency of mating types of Pyrenophora teres f. maculata and P. teres f. teres for the first time in Turkey. We also tested the hypothesis of multiplication of net blotch populations by sexual reproduction. A preliminary result of this study has been published (Çelik Oğuz et al., 2017).

\section{Materials and methods}

Collection of Pyrenophora teres isolates and obtaining single spore isolates. During the 2012-2013 and 2015-2016 growing seasons 270 diseased leaf samples were collected from barley fields at about every 30 kilometres in 28 different provinces (Manisa, Uşak, Denizli, Afyon, Edirne, Eskişehir, Konya, Aksaray, Ankara, Niğde, Kayseri, Nevşehir, Kırşehir, Çankırı, Kırıkkale, Yozgat, Sivas, Şırnak, Batman, Siirt, Mardin, Diyarbakır, Şanlıurfa, Adıyaman, Kilis, Gaziantep, Kahramanmaraş and Mersin) of Turkey (Fig. 1). From each field, 1-5 samples of diseased leaves were taken. Leaves exhibiting net and spot type symptoms were cut into small pieces and subjected to 1 minute of surface sterilization with $1 \%$ sodium hypochlorite. For obtaining single spores standard blotter technique for spore production was used (ISTA, 1996). Single spores were taken under a stereomicroscope and were placed onto potato dextrose agar (PDA). The majority of barley growing areas in Turkey are located in Central and Southeast Anatolia regions. Ninety percent of the isolates belong to these two regions. During the surveys $P$. teres f. maculata (Ptm) were more commonly observed. Among these 270 leaf samples, 175 samples (105 Ptm and $70 \mathrm{Ptt}$ ) were selected and single spore isolations were made. The two biotypes of pathogen were visually separated based on disease symptoms (Tekauz, 1985). For selection of these samples large barley planting areas of these two regions were considered. For each form of net blotch, isolates were selected from the fields representing the same field or different fields. During the 2015-2016 growing season, samples were taken from the Central and Southeast Anatolia regions of Turkey. In this growing season no samples were taken from the Marmara, Aegean and Mediterranean regions.

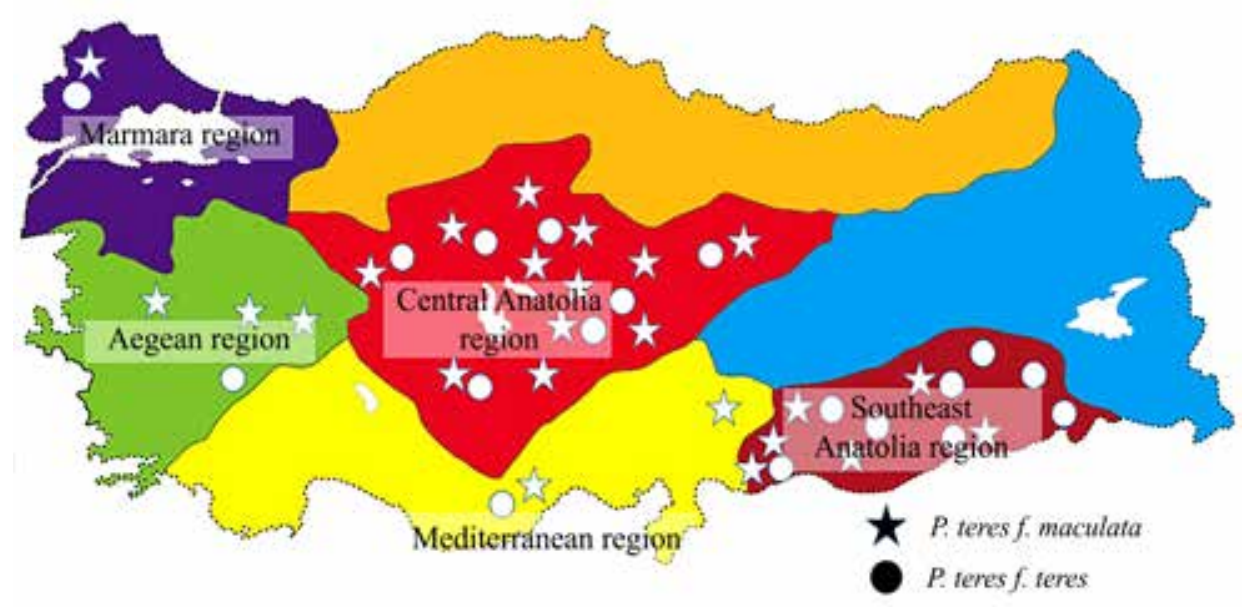

Figure 1. Collection locations of barley leaves infected with Pyrenophora teres f. maculata and P. teres f. teres in Turkey

Genomic DNA extraction from fungal cultures. Genomic DNA was extracted using the cetyltrimethylammonium bromide (CTAB) method modified by Allen et al. (2006). Briefly, cell walls of fungal mycelia were broken down by grinding tissue with MagNA lyser (Roche, Germany). The CTAB extraction buffer: 0.1 M Tris, $\mathrm{pH} 8.0,1.4 \mathrm{M} \mathrm{NaCl}, 0.02 \mathrm{M}$ ethylenediaminetetraacetic acid (EDTA), $5 \mathrm{~g}$ of CTAB, $0.5-1 \%(\mathrm{v} / \mathrm{v})$ of $\beta$-mercaptoethanol $(\beta \mathrm{ME})$, was added and samples were then incubated at $65^{\circ} \mathrm{C}$ for $30 \mathrm{~min}$. After centrifugation, the supernatant was transferred into new $2 \mathrm{~mL}$ tubes including phenol:chloroform:isoamyl alcohol (25:24:1). After new centrifugation step, aqueous phase was put into new tube and cold isopropanol was added. Precipitated DNA was solved in Tris-EDTA (TE) buffer (0.01 M Tris, $\mathrm{pH} 8.0$ and treated with DNAse free RNAse-A at $37^{\circ} \mathrm{C}$ for $30 \mathrm{~min}$ ). After a series of ethanol precipitation steps, DNA was cleaned up and allowed to 
air dry. Finally, the DNA was dissolved in $200 \mu \mathrm{l}$ of pure water and adjusted to a final concentration of $20{\mathrm{ng} \mu \mathrm{L}^{-1}}^{-1}$ in $\mathrm{TE}$ and stored at $-20^{\circ} \mathrm{C}$.

Species-specific and mating type form-specific duplex polymerase chain reaction (PCR) assays. PtGPD1 (control) primer pair (586 bp) was used for the species-specific PCR analysis (Lu et al., 2010) (Table $1)$. PCR reaction mixture was prepared as $25-\mu \mathrm{L}$ final volume containing $20 \mathrm{ng}$ of fungal genomic DNA, $1 \mu \mathrm{M}$ each primer, $1 \times$ MyTaq reaction buffer $\left(15 \mathrm{mM} \mathrm{MgCI}_{2}\right.$ and $5 \mathrm{mM}$ dNTPs), 0.125 units Taq DNA Polymerase (Bioline, USA). Cycling conditions were $95^{\circ} \mathrm{C}$ for $3 \mathrm{~min}$, 35 cycles of $15 \mathrm{~s}$ at $95^{\circ} \mathrm{C}, 15 \mathrm{~s}$ at $55^{\circ} \mathrm{C}$ and $10 \mathrm{~s}$ at $72^{\circ} \mathrm{C}$ with a final extension of $72^{\circ} \mathrm{C}$ for $30 \mathrm{~s}$. Pyrenophora tritici-repentis isolate was used as a negative control.

Diseased leaf samples were identified as spot or net forms of net blotch according to symptoms on barley leaves in the field. Assumed net blotch isolates were tested with $P$. teres species-specific primers in order to separate from other pathogens such as Cochliobolus sativus. A mating type form-specific duplex PCR analysis was performed using a set of single nucleotide polymorphism (SNP) primers Ptt MAT1-1F/R, Ptt MAT 1-2 F/R and Ptm MAT1-1 F/R, Ptm MAT1-2 F/R, described by $\mathrm{Lu}$ et al. (2010); PCR products: net form - Ptt MAT1-1 (1.143 bp) and Ptt MAT 1-2 (1.421 bp); spot form - Ptm MAT1-1 (194 bp) and Ptm MAT1-2 (939 bp) (Table 1). These primer pairs are also form-specific primers for Ptm and Ptt. Duplex PCR was performed separately for each form. PCR products mentioned in this study also differentiate between Ptm and Ptt isolates. PCR reaction mixture and cycling conditions were the same as described in the species-specific PCR assay with the exception of annealing temperature which was increased to $59^{\circ} \mathrm{C}$.

Table 1. Single nucleotide polymorphism (SNP) primers used in this study (Lu et al., 2010)

\begin{tabular}{|c|c|c|}
\hline Primer name & Primer sequence & Amplicon size \\
\hline PtGPD1-F & CGTATCGTCTTCCGCAAC & \multirow{2}{*}{$586 \mathrm{bp}$} \\
\hline PtGPD1-R & TTGGAGAGCACCTCAATGT & \\
\hline Ptt MAT1-1 F & ATGAGACGCTAGTTCAGAGTCT & \multirow{2}{*}{$1143 \mathrm{bp}$} \\
\hline Ptt MAT1-1 R & GATGCCCAGCCAAGGACAA & \\
\hline Ptt MAT1-2 F & TACGTTGATGCAGCTTTCTCAAT & \multirow{2}{*}{$1421 \mathrm{bp}$} \\
\hline Ptt MAT1-2 R & AACACCGTCCAAAGCACCT & \\
\hline Ptm MAT1-1 F & TGTTAGAGACCCCACCAGCGT & \multirow{2}{*}{$194 \mathrm{bp}$} \\
\hline Ptm MAT1-1 R & CAGCTTTCTTGGCCTTCTGAA & \\
\hline Ptm MAT1-2 F & ACGCAAGGTACTCTGTACGCA & \multirow{2}{*}{$939 \mathrm{bp}$} \\
\hline Ptm MAT1-2 R & GACGTCGAGGGAGTCCATTT & \\
\hline
\end{tabular}

PCR products were loaded on $1 \%$ agarose gels containing ethidium bromide with a concentration of $0.1 \mu \mathrm{g}$ $\mathrm{ml}^{-1}$ and electrophoresed in $0.5 \times$ Tris-borate-EDTA (TBE) for $1.5 \mathrm{~h}$ at $115 \mathrm{~V}$. Gels were photographed under UV light Quantum ST4 (Montreal Biotech, Canada). The sizes of the fragments in a gel were compared with GeneRuler $100 \mathrm{bp}$ DNA ladder Plus (MBI Fermentas, USA).

Statistical analysis. The $\chi^{2}$ significance test was used to determine whether the rate of mating type observed for $P$. teres populations in Turkey was clearly distinguished from the null hypothesis of the $1: 1$ ratio of MAT1:MAT2. The formula in which $\chi^{2}$ is calculated: $\chi^{2}=\sum\left[(\mathrm{o}-\mathrm{e})^{2} / \mathrm{e}\right]$, where $\mathrm{o}$ is the observed value of the mating type, $\mathrm{e}-$ the expected value of the mating type (Sommerhalder et al., 2006).

\section{Results and discussion}

One hundred seventy-five single spore isolates were obtained from different regions of Turkey and they were confirmed to be $P$. teres using the species-specific PtGPD1 (control) primer pair (Fig. 2).

The presence of both MAT1-1 and MAT1-2 mating types in both forms of net blotch in Turkey was observed using a mating type form-specific duplex PCR assay. Also, form-specific SNP primers used in our current study separated two forms of net blotch (Fig. 3). The two biotypes of pathogen were visually separated based on disease symptoms. The two biotypes of the samples that were separated as net form of net blotch or spot form of net blotch were subjected to form-specific duplex PCR.

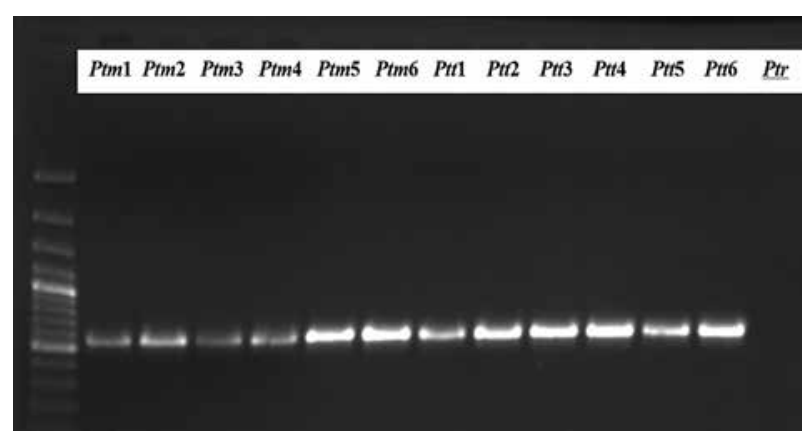

Note. Ptm - Pyrenophora teres f. maculata, Ptt - P. teres f. teres, Ptr - P. tritici-repentis; last line is negative control.

Figure 2. Species-specific PtGPD1 (control) primer pair $(586 \mathrm{bp})$ used in this study for confirmation of Pyrenophora teres isolates

As a result of this study, 3 isolates $(2.85 \%)$ previously identified as $\mathrm{Ptm}$ were determined as Ptt and 7 isolates $(10 \%)$ previously identified as $P t t$ were determined as Ptm. Thus, 109 single spore isolates of Ptm from 24 different provinces and 66 single spore Ptt isolates from 18 different provinces were obtained. Of the 109 Ptm isolates, 76 were obtained from Central Anatolia, 23 from Southeast Anatolia, 6 from Mediterranean, 3 from Aegean and 1 from Marmara regions of Turkey. Of the 66 $P t t$ isolates, 44 were obtained from the Central Anatolia, 20 from the Southeast Anatolia, 1 from Marmara and 1 from the Aegean regions of Turkey (Table 2).

MAT1-1 and MAT1-2 ratios of Ptm isolates during the 2012-2013 and 2015-2016 growing seasons 

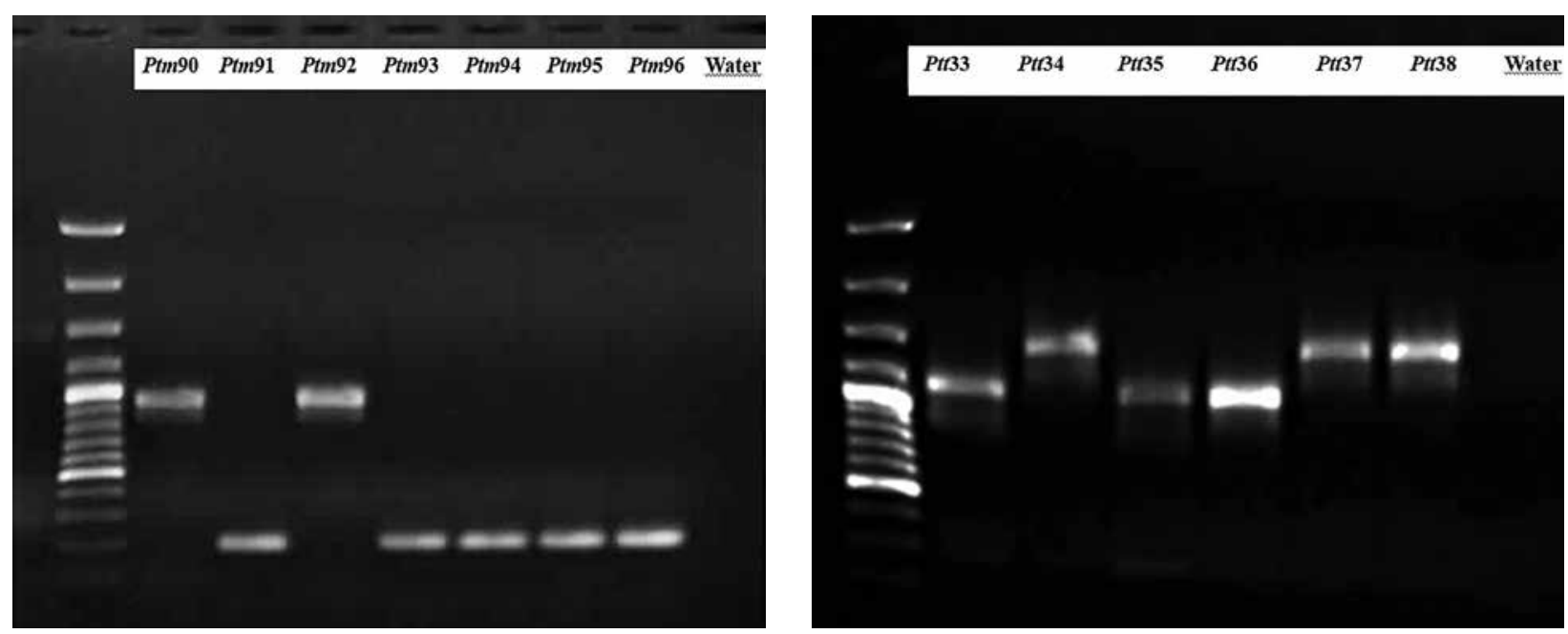

Figure 3. Multiplex PCR analysis of mating types of Pyrenophora teres f. maculata (Ptm) and P. teres f. teres (Ptt) in Turkey with single nucleotide polymorphism (SNP) primers Ptm MAT1-1, Ptm MAT1-2 and Ptt MAT1-1, Ptt MAT 1-2

Table 2. One hundred and seventy-five Pyrenophora teres (109 Ptm and $66 \mathrm{Ptt}$ ) isolates used in this study and their respective regions

\begin{tabular}{|c|c|c|c|c|c|c|c|c|c|c|}
\hline \multirow{3}{*}{ Growing seasons } & \multicolumn{10}{|c|}{ Regions } \\
\hline & \multicolumn{2}{|c|}{ Marmara } & \multicolumn{2}{|c|}{ Aegean } & \multicolumn{2}{|c|}{ Mediterranean } & \multicolumn{2}{|c|}{ Southeast Anatolia } & \multicolumn{2}{|c|}{ Central Anatolia } \\
\hline & Ptm & $P t t$ & Ptm & $P t t$ & Ptm & $P t t$ & Ptm & $P t t$ & Ptm & $P t t$ \\
\hline $2012-2013$ & 1 & 1 & 3 & 1 & 6 & - & 8 & 5 & 30 & 14 \\
\hline 2015-2016 & - & - & - & - & - & - & 15 & 15 & 46 & 30 \\
\hline Total & 1 & 1 & 3 & 1 & 6 & - & 23 & 20 & 76 & 44 \\
\hline
\end{tabular}

in Mediterranean, Southeast and Central Anatolia regions supported sexual reproduction hypothesis. However, only Ptt samples obtained from Central Anatolia region

supported this hypothesis. In some cases, both mating types (MAT1-1 and MAT1-2) were found in samples taken from the same field (Tables 3-6).

Table 3. Mating type distribution of Pyrenophora teres f. maculata populations obtained from different regions of Turkey during 2012-2013 and 2015-2016 growing seasons

\begin{tabular}{|c|c|c|c|c|c|c|c|c|c|c|}
\hline \multirow{3}{*}{$\begin{array}{l}\text { Growing } \\
\text { seasons }\end{array}$} & \multicolumn{10}{|c|}{ Regions } \\
\hline & \multicolumn{2}{|c|}{ Marmara } & \multicolumn{2}{|c|}{ Aegean } & \multicolumn{2}{|c|}{ Mediterranean } & \multicolumn{2}{|c|}{ Southeast Anatolia } & \multicolumn{2}{|c|}{ Central Anatolia } \\
\hline & MAT1-1 & MAT1-2 & MAT1-1 & MAT1-2 & MAT1-1 & MAT1-2 & MAT1-1 & MAT1-2 & MAT1-1 & MAT1-2 \\
\hline $2012-2013$ & 1 & - & 3 & - & 2 & 4 & 4 & 4 & 17 & 13 \\
\hline 2015-2016 & - & - & - & - & - & - & 8 & 7 & 25 & 21 \\
\hline Total isolates & 1 & - & 3 & - & 2 & 4 & 12 & 11 & 42 & 34 \\
\hline
\end{tabular}

Table 4. Mating type distribution and frequencies of Pyrenophora teres f. maculata populations obtained from different regions of Turkey

\begin{tabular}{lcccc}
\hline \multicolumn{1}{c}{ Regions } & MAT1-1 & MAT 1-2 & $\begin{array}{c}\chi^{2}(1: 1) \text { types } \\
(\mathrm{df}=1)\end{array}$ & $P$ \\
\hline Southeast Anatolia & 12 & 11 & 0.0435 & 0.8348 \\
Marmara & 1 & - & - & - \\
Mediterranean & 2 & 4 & 0.6667 & 0.4142 \\
Aegean & 3 & - & - & - \\
Central Anatolia & 42 & 34 & 0.8421 & 0.3588 \\
\hline Total & 60 & 49 & 1.1101 & 0.2921 \\
\hline
\end{tabular}

$\mathrm{df}$ - degrees of freedom

Of the $109 \mathrm{Ptm}$ isolates, $60(55.05 \%)$ were found to be $M A T 1-1$, while $49(44.95 \%)$ were found to be MAT1-2. Of the $66 \mathrm{Ptt}$ isolates, $43(65.15 \%)$ were found to be $M A T 1-1$, while $23(34.85 \%)$ were found to be MAT1-2. Among Ptm isolates, ratios of MAT1-1 and
MAT1-2 were similar, whereas among Ptt isolates, the idiomorph MAT1-1 was found to be more common.

The $\chi^{2}$ test confirmed that all of Ptm isolates were consistent with the 1:1 null hypothesis. It was observed that the hypothesis was also confirmed for the 
Table 5. Mating type distribution of Pyrenophora teres f. teres populations obtained from different regions of Turkey during 2012-2013 and 2015-2016 growing seasons

\begin{tabular}{ccccccccc}
\hline \multirow{2}{*}{$\begin{array}{c}\text { Growing } \\
\text { seasons }\end{array}$} & \multicolumn{9}{c}{ Regions } \\
\cline { 2 - 11 } & \multicolumn{2}{c}{ Marmara } & \multicolumn{2}{c}{ Aegean } & Southeast Anatolia & \multicolumn{2}{c}{ Central Anatolia } \\
\cline { 2 - 11 } & - & MAT1-2 & MAT1-1 & MAT1-2 & MAT1-1 & MAT1-2 & MAT1-1 & MAT1-2 \\
\hline $2012-2013$ & - & 1 & 1 & - & 4 & 1 & 9 & 5 \\
$2015-2016$ & - & - & - & - & 11 & 4 & 18 & 12 \\
\hline Total isolates & - & 1 & 1 & - & 15 & 5 & 27 & 17 \\
\hline
\end{tabular}

Table 6. Mating type distribution and frequencies of Pyrenophora teres f. teres populations obtained from different regions of Turkey

\begin{tabular}{lcccc}
\hline \multicolumn{1}{c}{ Regions } & MATl-1 & MAT $1-2$ & $\begin{array}{c}\chi^{2}(1: 1) \text { types } \\
(\mathrm{df}=1)\end{array}$ & $P$ \\
\hline Southeast Anatolia & 15 & 5 & 5.0000 & $0.0253^{*}$ \\
Marmara & - & 1 & - & - \\
Aegean & 1 & - & - & - \\
Central Anatolia & 27 & 17 & 2.2727 & 0.1317 \\
\hline Total & 43 & 23 & 6.0606 & $0.0138^{*}$ \\
\hline
\end{tabular}

df - degrees of freedom; * - significantly different mating-type frequencies that deviate from a 1:1 ratio $(P=0.05)$

Central and Southeast Anatolia and Mediterranean regions. The finding that the isolates showed no deviation from the 1:1 ratio supports the hypothesis that the fungus $P$. teres f. maculata reproduces sexually in its life cycle in Turkey. In the overall mating type patterns of $P t t$ isolates and in the isolates from the Southeast Anatolia regions, departures from the 1:1 ratio were observed. Isolates from the Central Anatolia region, on the other hand, showed no deviation from the 1:1 ratio. This finding suggests that in Turkey, fungus $P$. teres $\mathrm{f}$. teres reproduction type (sexual or asexual) may depend on the region. While the results suggest that the fungus reproduces sexually in the Central Anatolia region, this may not be the case in the Southeast Anatolia region where the results support the hypothesis that the pathogen reproduces asexually. Limited sample size obtained from regions other than Central Anatolia region may be responsible for these results. Serenius et al. (2005) reported that 1:1 ratio was obtained when sample size increased.

In order to assess the sexual recombination potential of $P$. teres, PCR-based mating type studies have been shown to be beneficial by many researchers (Rau et al., 2005; Serenius et al., 2005; Beattie et al., 2007; Lu et al., 2010; Akhavan et al., 2015). Rau et al. (2007) emphasized that in future studies the two forms should be evaluated separately and that well-defined net form or spot form isolates should be used to screen the barley genotypes. SNP primers used in our study were able to distinguish the two forms. SNP primers previously used by Lu et al. (2010) were used in our study. They stated that these primers successfully distinguished the two forms and were more useful than the PttMAT- and PtmMAT-related SNPs used in previous studies.

Researchers from various regions of the world have reported different results regarding the mating frequency distributions in $P$. teres populations. Rau et al. (2005) reported that sexual reproduction was at significant levels in both forms of $P$. teres in Sardinia, while Bogacki et al. (2010) suggested that the asexual component should not be neglected although reproduction was mainly sexual in the Ptt and Ptm populations in South Australia. Fiscor et al. (2014) reported that in Ptt populations in Hungary, idiomorphs of both mating types observed to be similar in frequency and that this should increase the sexual reproduction potential. Akhavan et al. (2015) concluded that in Canada, the two mating type genes were observed in equal frequencies in both forms of net blotch populations and the leading primary inoculum source was via sexual reproduction. On the contrary, Lehmensiek et al. (2010) reported that asexual reproduction was the dominant means of reproduction in both the Ptm and Ptt populations obtained from South Africa and the whole of Australia.

Peever and Milgroom (1994) observed random sexual reproduction in Alberta, North Dakota and German populations, but not in the New York population. Jonsson et al. (2000) pointed out that while in the P. teres cultivar 'Svani' population asexual reproduction was observed, on the overall pattern, the Swedish population might have a sexual reproduction cycle. Serenius et al. (2007) observed only the MAT2 idiomorph in Krasnodar (Russia), however, found the mating type ratio (MAT1 and MAT2) to be 1:1 in several locations in Australia and Finland. Statkevičiūtè et al. (2010) found both mating types in Lithuania Ptt populations with a 1:1 ratio with the exception of Klaipeda population. These studies showed that the distribution and genetic differentiation of $P$. teres sexual reproduction were quite variable between different geographical regions. Also in our current study, the mating type ratio in the Ptt population showed variation from region to region. While the 1:1 hypothesis was shown to be true for the Central Anatolia region, in the remaining regions, it was not the case.

In a given region, the mating type ratio of the pathogen might fluctuate over the years. Robinson and Jalli (1996), Jalli and Robinson (2000) and Robinson and Mattila (2000) reported that the pathogen reproduced mainly asexually in Finland; however, Serenius et al. 
(2005) reported that the mating type ratio in Finland did not deviate from 1:1 and sexual reproduction was common among the Finnish $P$. teres populations. Their study was the first to observe sexual reproduction in P. teres in Finland.

The only study on the biology of the spot form of net blotch in Turkey was performed by Karakaya et al. (2004). In this study, infected leaves collected from the Central Anatolia region were kept under and above ground. Pseudothecia of the pathogen were observed on the leaves left on the ground and buried, but no ascospores were detected. This finding supports the hypothesis that in the Central Anatolia region in Turkey, the P. teres f. maculata can reproduce sexually. There has been no study on the biology of the Ptt in Turkey. The presence and frequency of mating types in both forms have been reported with the current study for the first time in Turkey.

Mutation, population size and random genetic drift, gene and genotype flow, reproduction and mating system, selection imposed by major gene resistance and quantitative resistance affect pathogen evolution. Understanding the factors that affect pathogen evolution will help to develop control strategies against net blotch. When the pathogen population is small, the mutations are not as important as sexual reproduction. It has been reported that if the asexual spores of the pathogen fungus are able to travel long distances, a high risk for causing an epidemic through migration and gene flow is possible (Burdon, Silk, 1997; McDonald, Linde, 2002). However, in P. teres, the potential of conidial spread is thought to be limited. In fungi, reproduction is observed to be either sexual, asexual or mixed in places where both sexual and asexual reproduction is present. Pathogens with mixed reproduction systems (sexual + asexual) are believed to carry the most risk for evolution (McDonald, Linde, 2002). In Turkey, P. teres is believed to have a mixed reproduction system as shown in our study in which in addition to asexual reproduction, $P$. teres $f$. maculata also exhibited sexual reproduction in its life cycle all around Turkey (Karakaya et al., 2004, and this study), while $P$. teres $f$. teres exhibited sexual reproduction in the Central Anatolia region.

Genotype variation is high in pathogen populations that exhibit sexual reproduction. Many new combinations of alleles in sexual reproduction lead to novel genotypes and this is one of the most important risks for control of the pathogen because the novel genotypes can be more virulent than the previous ones and overwhelm the hosts' genetic durability. Methods that prevent development of sexual reproduction have been implicated as possible disease management strategies (McDonald, Linde, 2002; Beattie et al., 2007). In Turkey, $26 \mathrm{Ptm}$ and $24 \mathrm{Ptt}$ pathotypes have been discovered, suggesting that pathogenic variation was high (Çelik Oğuz, Karakaya, 2017).

Mating type surveys are the most practical method to assess the sexual and recombination potential in some species. In heterothallic species, populations that only have one mating idiomorph cannot mate randomly. However, if they do mate randomly, the mating ratio is expected to be $1: 1$. It is observed without exception that sexual populations have more genetic diversity than asexual populations in the same fungal species. Rejection of null hypothesis in mating type tests means that there is no random mating in the population. However, caution should be exercised about reaching conclusions related to sexual reproduction in the populations. Rejection of the random mating hypothesis means that the recombination can occur in a regular manner (Milgroom, 1996).

\section{Conclusions}

1. This is the first study dealing with mating types of both forms of Pyrenophora teres in Turkey.

2. P. teres f. maculata (Ptm) was found more common in Turkey. We obtained 109 (62.2\%) Ptm and 66 $(37.8 \%)$ P. teres f. teres (Ptt) isolates. The majority of the samples were taken from Central and Southeast Anatolia regions of Turkey where most barley production occurs.

3. Form-specific single nucleotide polymorphism (SNP) primers successfully separated two $P$. teres forms. As a result of form-specific duplex PCR study, 3 (2.85\%) isolates previously identified as Ptm were determined as $P t t$, and $7(10 \%)$ isolates previously identified as $P t t$ were determined as Ptm.

4. Both mating types of spot and net forms of $P$. teres have been found in Turkey. It appears that Ptm population $(\chi 2(1: 1)$ types $=1.1 ; P=0.29)$ in Turkey and Central Anatolia population of Ptt $(\chi 2$ (1:1) types = 2.2; $P=0.13)$ have a mating type with similar frequencies and these support the sexual reproduction hypothesis. However, $P t t$ population in Turkey $(\chi 2$ (1:1) types $=$ $6.06 ; P=0.01)$ did not approximate to $1: 1$ ratio. Limited sample size obtained from regions other than Central Anatolia region may be responsible for these results.

5. Central Anatolia region is an important barley production area in Turkey. Sexual reproduction in $P$. teres appears to be significant in certain regions of Turkey since conidia of $P$. teres cannot travel long distances. As a result of sexual reproduction, fungus may produce more virulent pathotypes in the future. Using mating type surveys to monitor the pathogen and comparing isolates collected with long time intervals with each other will make follow-up of genetic variations possible and will help in cultivation of durable plants as well as adoption of effective control strategies.

Received 03102017

Accepted 06042018

\section{References}

1. Akhavan A., Turkington T. K., Kebede B., Tekauz A., Kutcher H. R., Kirkham C., Xi K., Kumar K., Tucker J. R., Strelkov S. E. 2015. Prevalence of mating type idiomorphs in Pyrenophora teres f. teres and Pyrenophora teres f. maculata populations from the Canadian prairies. Canadian Journal of Plant Pathology, 37: 52-56. https://doi.org/10.1080/07060661.2014.995710

2. Akhavan A., Turkington T. K., Askarian H., Tekauz A., Xi K., Tucker J. R., Kutcher R., Strelkov S. E. 2016. Virulence of Pyrenophora teres populations in western Canada. Canadian Journal of Plant Pathology, 38: 183-196. https://doi.org/10.1080/07060661.2016.1159617

3. Allen G. C., Flores-Vergara M. A., Krasynanski S., Kumar S., Thompson W. F. 2006. A modified protocol for rapid DNA isolation from plant tissues using cetyltrimethylammonium bromide. Nature Protocols, 1: $2320-2325$.

https://doi.org/10.1038/nprot.2006.384 
4. Beattie A. D., Scoles G. J., Rossnagel B. G. 2007. Identification of molecular markers linked to a Pyrenophora teres avirulence gene. Phytopathology, 97: 842-849. https://doi.org/10.1094/PHYTO-97-7-0842

5. Bogacki P., Keiper F. J., Oldach K. H. 2010. Genetic structure of South Australian Pyrenophora teres populations as revealed by microsatellite analyses. Fungal Biology, 114: 834-841.

https://doi.org/10.1016/j.funbio.2010.08.002

6. Boungab K., Belabid L., Fortas Z., Bayaa B. 2012. Pathotype diversity among Algerian isolates of Pyrenophora teres f. teres. Phytopathologia Mediterranea, 51: 577-586.

7. Burdon J. J., Silk J. 1997. Sources and patterns of diversity in plant-pathogenic fungi. Phytopathology, 87: 664-669. https://doi.org/10.1094/PHYTO.1997.87.7.664

8. Campbell G. F., Lucas J. A., Crous P. W. 2002. Evidence of recombination between net- and spot-type populations of Pyrenophora teres as determined by RAPD analysis. Mycological Research, 106: 602-608. https://doi.org/10.1017/S0953756202005853

9. Çelik Oğuz A., Karakaya A. 2017. Pathotypes of Pyrenophora teres on barley in Turkey. Phytopathologia Mediterranea, 56 (2): 224-234.

10. Çelik Oğuz A., Ölmez F., Karakaya A. 2017. A preliminary study of Pyrenophora teres mating type distribution in Turkey. International Workshop Plant Health: Challenges and Solutions. Antalya, Turkey, p. 65.

11. Debuchy R., Turgeon B. G. 2006. Mating-type structure, evolution, and function in Euascomycetes. Kues U., Fischer R. (eds). The Mycota. Growth, differentiation and sexuality. Berlin, Germany, vol. I, p. 293-323.

https://doi.org/10.1007/3-540-28135-5 15

12. Ficsor A., Tóth B., Varga J., Csosz M., Tomesányi A., Mészáros K., Kótai É., Bakonyi J. 2014. Variability of Pyrenophora teres f. teres in Hungary as revealed by mating type and RAPD analyses. Journal of Plant Pathology, 96: 515-523.

13. ISTA. 1996. International rules for seed testing. Seed Science and Technology, 24: 1-335.

14. Jalli M., Robinson J. 2000. Stable resistance in barley to Pyrenophora teres f. teres isolates from the NordicBaltic region after increase on standard host genotypes. Euphytica, 113: 71-77. https://doi.org/10.1023/A:1003912825455

15. Jonsson R., Sail T., Bryngelsson T. 2000. Genetic diversity for random amplified polymorphic DNA (RAPD) markers in two Swedish populations of Pyrenophora teres. Canadian Journal of Plant Pathology, 22: 258-264. https://doi.org/10.1080/07060660009500473

16. Karakaya A., Katırcıoğlu Y. Z., Aktaş H. 2004. Studies on the biology of Drechslera teres under Ankara conditions. Tarım Bilimleri Dergisi, 10: 133-135. https://doi.org/10.1501/Tarimbil_0000000882

17. Karakaya A., Mert Z., Çelik Oğuz A., Azamparsa M. R., Çelik E., Akan K., Çetin L. 2014. Current status of scald and net blotch diseases of barley in Turkey. $1^{\text {st }}$ International Workshop on Barley Leaf Diseases. Salsomaggiore Terme, Italy, p. 31

18. Kronstad J. W., Staben C. 1997. Mating type in filamentous fungi. Annual Review of Genetics, 31: 245-276. https://doi.org/10.1146/annurev.genet.31.1.245

19. Lehmensiek A., Bester A. E., Sutherland M. W., Platz G., Kriel W. M., Potgieter G. F., Prins R. 2010. Population structure of South African and Australian Pyrenophora teres isolates. Plant Pathology, 59: 504-515. https://doi.org/10.1111/j.1365-3059.2009.02231.x

20. Liu Z., Ellwood S. R., Oliver R. P., Friesen T. L. 2011. Pyrenophora teres: profile of an increasingly damaging barley pathogen. Molecular Plant Pathology, 12: 1-19. https://doi.org/10.1111/j.1364-3703.2010.00649.x
21. Lu S., Platz G. J., Edwards M. C., Friesen T. L. 2010. Mating type locus specific polymerase chain reaction markers for differentiation of Pyrenophora teres f. teres and $P$. teres f. maculata, the causal agents of barley net blotch. Phytopathology, 100: 1298-1306. https://doi.org/10.1094/PHYTO-05-10-0135

22. Mathre D. E. (ed.). 1982. Compendium of barley diseases. Minnesota, USA, $78 \mathrm{p}$.

23. McDonald B. A. Linde C. 2002. Pathogen population genetics, evolutionary potential, and durable resistance. Annual Review of Phytopathology, 40: 349-379. https://doi.org/10.1146/annurev.phyto.40.120501.101443

24. McLean M. S., Howlett B. J., Hollaway G. J. 2009. Epidemiology and control of spot form of net blotch (Pyrenophora teres f. maculata) of barley: a review. Crop and Pasture Science, 60: 499-499. https://doi.org/10.1071/CP08173_ER

25. Milgroom M. G. 1996. Recombination and the multilocus structure of fungal populations. Annual Review of Phytopathology, 34: 457-477. https://doi.org/10.1146/annurev.phyto.34.1.457

26. McLean M. S., Martin A., Gupta S., Sutherland M. W., Hollaway G. J., Platz G. J. 2014. Validation of a new spot form of net blotch differential set and evidence for hybridisation between the spot and net forms of net blotch in Australia. Australasian Plant Pathology, 43: 223-233. https://doi.org/10.1007/s13313-014-0285-8

27. Murray G. M., Brennan J. P. 2010. Estimating disease losses to the Australian barley industry. Australasian Plant Pathology, 39: 85-96. https://doi.org/10.1071/AP09064

28. Peever T. L., Milgroom M. G. 1994. Genetic structure of Pyrenophora teres populations determined with random amplified polymorphic DNA markers. Canadian Journal of Botany, 72: 915-923. https://doi.org/10.1139/b94-116

29. Rau D., Maier F. J., Papa R., Brown A. H. D., Balmas V., Saba E., Schaefer W., Attene G. 2005. Isolation and characterization of the mating-type locus of the barley pathogen Pyrenophora teres and frequencies of matingtype idiomorphs within and among fungal populations collected from barley landraces. Genome, 48: 855-869. https://doi.org/10.1139/g05-046

30. Rau D., Attene G., Brown A. H. D., Nanni L., Maier F. J., Balmas V., Saba E., Schäfer W., Papa R. 2007. Phylogeny and evolution of mating-type genes from Pyrenophora teres, the causal agent of barley 'net blotch' disease. Current Genetics, 51: 377-392. https://doi.org/10.1007/s00294-007-0126-1

31. Robinson J., Jalli M. 1996. Diversity among Finnish net blotch isolates and resistance in barley. Euphytica, 92: 81-87. https://doi.org/10.1007/BF00022832

32. Robinson J., Mattila I. 2000. Diversity and difference within and between Pyrenophora teres f. teres populations measured with Kosman's indices. Archiv für Phytopathologie und Pflanzenschutz, 33: 11-23. https://doi.org/10.1080/03235400009383324

33. Serenius M., Mironenko N., Manninen O. 2005. Genetic variation, occurrence of mating types and different forms of Pyrenophora teres causing net blotch of barley in Finland. Mycological Research, 109: 809-817. https://doi.org/10.1017/S0953756205002856

34. Serenius M., Manninen O., Wallwork H., Williams K. 2007. Genetic differentiation in Pyrenophora teres populations measured with AFLP markers. Mycological Research, 111: 213-223. https://doi.org/10.1016/j.mycres.2006.11.009

35. Smedegård-Petersen V. 1971. Pyrenophora teres f. sp. maculata f. nov and Pyrenophora teres f. teres on barley in Denmark. Yearbook of Royal Veterinary and Agricultural University, Copenhagen, Denmark, p. 124-144. 
36. Sommerhalder R. J., McDonald B. A., Zhan J. 2006. The frequencies and spatial distribution of mating types in Stagonospora nodorum are consistent with recurring sexual reproduction. Phytopathology, 96 (3): 234-239. https://doi.org/10.1094/PHYTO-96-0234

37. Statkevičiūtè G., Brazauskas G., Semaškienė R., Leistrumaitė A., Dabkevičius Z. 2010. Pyrenophora teres genetic diversity as detected by ISSR analysis. Zemdirbyste-Agriculture, 97 (4): 91-98.

38. Tekauz A. 1985. A numerical scale to classify reactions of barley to Pyrenophora teres. Canadian Journal of Plant Pathology, 7: 181-183.

https://doi.org/10.1080/07060668509501499
39. Turkington T. K., Tekauz A., Xi K., Kutcher H. R. 2011. Foliar diseases of barley: don't rely on a single strategy from the disease management toolbox. Prairie Soils Crops, 4: $142-150$.

40. Yazıcı B., Karakaya A., Çelik Oğuz A., Mert Z. 2015. Determination of the seedling reactions of some barley cultivars to Drechslera teres f. teres. Plant Protection Bulletin, 55: 239-245.

ISSN 1392-3196 / e-ISSN 2335-8947

Zemdirbyste-Agriculture, vol. 105, No. 3 (2018), p. 271-278

DOI 10.13080/z-a.2018.105.035

\title{
Pyrenophora teres dauginimosi tipo idiomorfos Turkijoje
}

\author{
A. Çelik Oğuz', F. Ölmez², A. Karakaya ${ }^{1}$ \\ ${ }^{1}$ Ankaros universitetas, Turkija \\ ${ }^{2}$ Şırnak universitetas, Turkija
}

\section{Santrauka}

Pyrenophora teres f. maculata (Ptm) ir Pyrenophora teres f. teres (Ptt) sukelia dèmètają ir tinkliškają miežių dryžligę. Nors abi $P$. teres formos yra morfologiškai panašios, jų simptomai ir genetinè kilmè skiriasi. Tyrimo metu vertintas 175 vienos sporos (109 Ptm ir $66 \mathrm{Ptt}$ ) izoliatų, gautų iš įvairių Turkijos regionų, dauginimosi tipas ir jų tarpusavio santykis. Abiejų formų grybų izoliatai tirti naudojant polimerazès grandininès reakcijos (PGR) rūšiai specifinius pradmenis. Dauginimosi tipas nustatytas taikant dvigubą PGR, dauginimuisi naudojant MAT specifinius pradmenis. Iš 109 Ptm izoliatų buvo nustatyta 60 MAT1-1 ir 49 MAT1-2 tipai, o iš 66 Ptt izoliatų - 43 MAT1-1 ir 23 MAT1-2 tipai. Tyrimo rezultatai rodo lytinio dauginimosi galimybę tarp Ptm izoliatu Turkijoje ir Ptt populiacijos Centrinejje Anatolijoje, Turkijoje. Tačiau bendra Ptt izoliatų struktūra nepatvirtino lytinio dauginimosi hipotezès Turkijoje. Lytinis dauginimasis $P$. teres gyvenimo cikle yra svarbus, nes jis gali lemti genetinę ir patogeninę variaciją. Dèl naujų lytinio dauginimosi kombinacijų gali atsirasti virulentiškesni $P$. teres patotipai.

Reikšminiai žodžiai:, Drechslera teres f. maculata, Drechslera teres f. teres, miežiai. 